\title{
Radio Broadcasting as Nazi Propagandistic Tool
}

\author{
Youngho Yoo
}

\begin{abstract}
The term propaganda sounds somewhat modern; however, propaganda has never been ignored in different types of regimes - kingdoms, empires, nation-states, etc. - through history. Political unities always attempted to find more effective ways to maintain power, keeping status quo with neighboring political unities, or sometimes manipulate the public in accordance with their needs. For instance, the Athenians, Romans and the other ancients advertised propagandistic messages through media such as coins, myths, visual images etc. Textiles that were conveniently movable and displayable also performed as the effective propagandistic medium. Thus, regarding the nature and purpose of propaganda, it always delivered political messages as fast as it could, and had to make as many people as contact them. Ultimately it should motivate and mobilize people (i.e. the mass) as a regime wished.
\end{abstract}

Around the 1910s, the new technology, radio, was invented. However, this "air-wave" medium had never been considered as a political medium by statesmen, before Joseph Goebbels who became a minister of propaganda in the Third Reich. Goebbels never underestimated the potentiality of radio; the radio was viewed as a perfect propagandistic tool. Radio was one of the most effective propagandistic methods, as the Nazis can centralize the propaganda tool, then deliver political messages fast and continuously, reaching to individual home, and contacting all ranges of people - even the illiterate and poor. Regulating radio broadcasting as the major propaganda method, radio broadcasting played an important role throughout the period of the Nazi regime. That is, the Nazis could ultimately motivate and mobilize the Germans during the war time. After the downfall of Nazi Germany, the power of radio was re-estimated by different countries throughout the twentieth century. Radio has been used as an intangible medium - Air Wave - in politics. As Nazi Germany manipulated radio broadcasting in politics, the example of Nazi radio broadcasting shows how the new technology can be applied in political life.

Index Terms - Nazi propaganda, propagandistic tool, radio broadcasting, technologies in politics.

\section{INTRODUCTION}

The Weimar Republic failed to establish legitimacy in Germany, and German society was not economically or politically stable throughout the entire period of the Republic. The reparation and influence of the Great Depression destroyed the German economy. Moreover, German society was deeply dispersed, as several extreme political movements of the far right and far left parties became more active and visible at the end of the Weimar Republic. Among political parties in the struggle for

Manuscript received November 14, 2016; revised March 1, 2017

Youngho Yoo is with the History in Progress at King's College London, UK (e-mail: youngho.yoo@mail.utoronto.ca) absolute power, the NSDAP had the ability to enter the Reichstag. It later became the strongest and sole political party of Nazi Germany, and it eventually succeeded holding dictatorship and establishing a totalitarian state until the end of the Second World War. The political victory of the Nazis was not simply a result of physical tactics. Through the use of a paramilitary group famously known as the SA (Sturmabteilung), the Nazi party acknowledged that the manipulation of the mass through propaganda would be necessary in order to integrate the 'national community.' Since they started as a small local party, Hitler and highranking Nazi members realized that controlling the German population would be the key to actualizing their extreme and fanatic goals. To accomplish this, various propaganda methods were introduced in the Reich.

In addition to other propagandistic tools, radio broadcasting had a powerful influence on German society. It allowed the Nazi authority to project its goal onto the German masses even though radio broadcasting was a relatively new form of broadcasting at the time. Joseph Goebbels, assigned to the Ministry of Propaganda and Public Enlightenment in March of 1933, exercised more direct power on radio broadcasting. First of all, the integration of Germans was seen as one of most important premises to Nazi authority. Radio broadcasting was a perfect propaganda tool, as it could easily be centralized and controlled. Secondly, the Nazi authority could lead Germans to conform to one 'national community' and could continue delivering its messages through radio broadcasting. Since radio broadcasting was based on spoken words and entertainment, the Nazi Authority could influence the German population regardless of class, education or gender. The last point is that the Nazi authority not only provided information, but also motivated and mobilized the German people.

This paper will show how the Nazi authority utilized and manipulated radio broadcastings in order to integrate German society and actualize its goal. In each part, prominent elements for managing propaganda successfully will be explained, and the effectiveness of Nazi radio broadcastings will be illustrated through several examples. I will then explain what resulted from the successful manipulation of broadcastings, such as an integrated national feeling, Germans participating in total war, mass killing and other occurrences. First of all, the process of the centralization of radio broadcastings and German society will be examined. Next, I will look at how Nazi Germany took advantage of radio broadcastings, and explain the function of continuity and repetition in these broadcasts. Lastly, it will be demonstrated how radio broadcastings was working in Nazi propaganda as one of the most important propagandistic methods to motivate and mobilize the German people including 'ordinary' people. 


\section{Centralization OF RAdio BROAdCASTING}

First of all, the Nazi authority needed to centralize broadcasting in order to easily control the public mass and mass media. To do so, the Nazi regime directly manipulated radio broadcasting throughout the entire duration of the regime. Although radio broadcasting had existed since the 1910 s, this was a very new technology in the twentieth century, and was not regarded as an effective tool for government [1]. The Nazis discovered the propagandistic value of this new medium. Particularly, Joseph Goebbels once said that, "what the press was for the nineteenth century, the radio will be for the twentieth century. [2]" For the successful advertisement of propaganda, the Nazis acknowledged that they needed to send messages that contained identical content without regional and societal differences. Radio broadcasting would satisfy this requirement for the Nazis, as it was easier to centralize than other forms of mass media. The centralization of radio broadcasting was less-expensive and less-time consuming than other propaganda media.

Nazi Germany organized a bureaucratic body for radio broadcasting. This meant that the sole bureaucratic body could be easily and directly controlled by the Nazi regime. The Ministry of Propaganda and Public Enlightenment was established, and a branch was set up for radio broadcasting in 1933. There were three major agencies that controlled German radio broadcasting. Firstly, The Propaganda Ministry, in which Goebbels controlled the content. Next, the National Socialist Party organized and supervised listeners and the Reich Chamber of Culture. Then, they did practical jobs, such as organizing the producers, broadcasters, writers and other employees [3]. The administrative management of the radio was also divided for more effective advertising. The Director General was in charge of all programs related to politics directly, such as news reports, commentaries, counterpropaganda, and broadcasting to foreign countries. The other part was the Program Division, which managed all other content, such as musical programs, dramas, educational talks, general entertainment, and so on [4]. The bureaucracy was tremendously specified, as were other aspects of the Nazi regime. The system was converged to Goebbels, as he appointed the heads of each branch with people that were personally connected to him. The bureaucratic organization of radio broadcasting became the more effective it was. Nazi Germany continued using these tactics until the end of the war.

The effect of centralization in broadcasting radio benefitted the Nazis because it allowed them to control Germans easily, cheaply, and quickly. Goebbels, the head of the Ministry, could send his and Hitler's messages directly by controlling other branches in the Ministry more strictly than other media. This was because the broadcasting was done through air-waves; therefore, the Nazi regime did not need to control various forms of media. For example, at the time there were diverse local papers all around the German territory, all with different content. As radio broadcasting was called the mouth of Goebbels, the success in centralizing radio broadcasting allowed the Nazi regime to control the mass media in a more effective manner.

\section{NATIONAL INTEGRATION OF GERMANS}

Second of all, the effect that (centralized) radio broadcasting had was that it eventually allowed the Nazis to strengthen national identity and encourage the Germans into national integration. A unified 'national identity' was very important to the Nazi regime. Continuously mentioning the stab-in-the-back myth, the Nazi regime not only executed Reich enemies, but also attempted to unify Germans into one 'national community' for their ultimate and fanatic goals: War and Thousand-Year Reich. Radio broadcasting was an effective strategy for achieving this end. The one characteristic of radio broadcasting was that the German radio repeated certain themes over time. Effective propaganda should be restricted to a few themes and slogans, and these should be repeated multiple times in order to ideologically integrate a population. For example, German radio emphasized that the German army was never defeated in an honest war (WWI), but rather the war was lost on the home front. Playing off of this, German radio kept denouncing the Jews and the disgracing of the Versailles treaty [5]. Most core themes were related to a symbol of German strength, führership, heroism of soldiers who sacrificed their lives for the 'greater good,' and the weakness of their enemies [6]. For instance, there were specific topics: "World Power Germany," "Germany's Unity - Germany's Destiny," "The Ninth of November," and so on [7]. Once, Hitler emphasized, "Whatever change may be introduced for variety's sake, must never affect the content of the message but must always say the same thing in the end. [8]" As a tool of propaganda, radio was perfect for delivering political messages continuously over time. In regards to public Nazi propaganda, there were apparently a large number of public speeches. For example, there was the well-known Nuremberg Rally speech. Nevertheless, it was not enough for Hitler and the Nazi party to deliver their propaganda messages exclusively through speeches. By repeating core themes through radio broadcasting, the entire German population could have the same impression and image from a psycho analytical perspective. That is, the Nazi regime could achieve national integration through ideological means.

Another feature showing the effectiveness of radio (as a propagandistic medium) was that the Nazi regime was able to integrate Germans regardless of socioeconomic classes, regions, and genders. To send identical messages to the entire population, the Nazi regime endeavored that radio broadcasting should be listened to by as many Germans as possible. In order to do this, the Nazi regime made the price of a radio set cheaper. It was only $76 \mathrm{DM}$, which was a 2 week-salary of a manual worker in May 1933, and it became less than half that price by 1938 [9]. The party even provided free licenses to those who could not afford the fee for a radio set [10]. Right before the war, most German families had a radio receiver. The number of subscribers was 4.5 million in 1933, and rose to 16 million by 1941 [11]. The distribution rate of the radio receiver was highest in the world and, as a result, German citizens who came from different backgrounds could listen to identical messages from the centralized government. The Nazi regime could not send more unified messages through the press due to that fact that it was diverse. For example, there was Frankfurter 
Zeitung, and Deutsche Allgemeine Zeitung which were read by executives, professionals, and the educated. Das Schwarze Korps was the press for the SS units, and talked about public morale and supervision. Local papers also gave other information, such as reports on air-raid damage and rumors [12]. Unlike the diversity of the press, radio broadcasting could send messages to all people, including the uneducated (who were probably illiterate), women who were behind the scenes, and old people. By receiving governmental messages, the German population became entirely integrated at the national level. This process was almost completed before the beginning of the Second World War. Due to radio broadcasting, which continued to reach any German individual up until the end of the war, the fanatic German national integration became an important basis for the Nazis to start the Second World War.

\section{Motivating the Germans through Air-WaVE}

Last but not least, radio broadcasting was a powerful tool, as it motivated and mobilized the Germans into conformity, and fueled war efforts until the end of the Second World War. One of the prominent goals of propaganda is that propaganda should not end up merely advertising itself and providing information [13]. For an authoritative and totalitarian regime - including the Nazi regime propaganda is a tool that delivers practical and abstract ideologies in order to convince the public to agree with aims of the regime. The Nazi authority realized the importance of radio broadcasting in this sense, as Hitler once argued in Mein Kempf. The manipulation of radio broadcasting allowed the Nazis to centralize the broadcasting and conform to the 'national community.' Additionally, according to Kallis, the Nazi authority was able to manage behavioral and attitudinal patterns among its audience in order to generate the desired action [14]. Germans were highly affected by political messages and aggressive polemics since the Nazi authority began radio broadcasting. From 1933 to the early period of the war when Nazi Germany found it could achieve its goals faster than anticipated, German radio focused on content that usually contained serious political messages. Germans were conscious of content and political messages of the Nazis. Moreover, German radio motivated and mobilized the German population by broadcasting entertaining content which was very carefully selected and organized by the Nazi regime.

The phenomenon of increasing entertainment content appeared particularly after 1942. Goebbels and the Ministry had to reorganize radio broadcasting after the Battle of Britain, along with several prominent defeats in battles in Soviet territories, which were not satisfying to Nazi Germany [15]. Wolfgang Fischer, who was a head of the RPL radio office, argued the need for a human-interest touch [16]. The Nazi authority delivered broadcasts more oriented to social, personal, and human needs, and less focused on direct polemics and political messages with the war and foreign affairs. Radio entertainment increased continuously during the war years. The 1:1 ratio during the early years of the Nazi regime changed to a 2:1 ratio by early 1939. Finally, after reorganization, the ratio became 4:1 by 1943/44 [17]. Eighteen out of twenty one hours were devoted to radio entertainment [18]. Through educational talks, commentators emphasized that Germans are now standing in the middle of history. Commentators also repeated the justification for the war against Jews, Russians and other Reich-enemies. As a result, the mass was brainwashed and tended to doubt the war situation. Rather, the occasional hours of broadcasting entertainment made listener feel that he or she was living through great times and stirring events. Radio provided the masses with the privilege of witnessing history in the making, and encouraged them to take part [19]. Consequently, the Germans kept fanatically participating in the total war.

German radio made Germans hyper enthusiastic toward the war through musical content as well. As the other aspect of propaganda is that it should be long-term, this type of propaganda cultivated the attitudes, beliefs and perceptions of the masses. That is, the Germans who were inspired by entertaining content - which was highly refined and politically delivering Nazi messages - became fanatics over time. The musical content began to increase on German radio. Goebbels commanded German radio to never stop presenting German military music. For instance, when Nazi Germany attacked the Balkans on April 6, 1941, the German radio was broadcasting 'Prinz Eugen March,' with its evocation of an Austrian military hero of the early eighteenth century during the Turkish wars [20]. Other examples included "Es ist so schon soldat zu sein," "Siegreich woll'n wir Frankreich schlagen," and "Bomben auf En-ge-land." These were cheerful greetings from the front and for the family [21]. German radio carefully selected musical content. It did not allow musical content that could produce a negative effect in stimulating people. For instance, Mozart's Requiem was not allowed to play due to its "depressing and world-renouncing" text. The Fifth Symphony of Beethoven was not allowed either [22]. Despite a plethora of German composers at its disposal, Nazi Germany was very careful in sorting out what should be broadcasted. The series of martial and heroic music, which could only be delivered through radio broadcasting, apparently worked for both soldiers in war fronts and civilians on the home front. By making soldiers distracted from hardships, Nazi Germany could consolidate the military morale, and manipulate them to keep sacrificing themselves for the 'national community' and fight even more fanatically. On the home front, it was possible for Nazi Germany to go through total war, with Germans from different socioeconomic classes joining the war at different levels.

\section{CONCLUSION}

Anticipating the effects of radio broadcasting, Germans joined the Nazis actively starting in 1933, the time the Nazis established the Ministry of Propaganda and Public Enlightenment. Nazi Germany, especially after holding sole power, began to actualize their goals. German communists were arrested around the time that Hitler gained absolute power through Article 48. In 1935, the Nazi regime 
regulated the Nuremberg Laws to distinguish who were legitimate to be 'genuine' Germans, and able to keep citizenship. In 1938, the Jewish persecution took place physically, as the Kristallnacht happened all over Germany. The series of fanatical events could not have occurred without the active participation of 'ordinary' Germans.

The manipulation of broadcasting in Nazi Germany was very powerful, and satisfying for the Nazi authority. Radio broadcasting was an effective propagandistic tool for integrating German society and making them support Nazi goals, which ranged from actualizing an integrated genuineGerman society to fighting with Reich enemies. It was easy for the Nazi regime to centralize radio broadcasting and send messages directly, compared to other forms of media. Radio broadcasting could reach any region and any German individual; therefore, it brought the 'national community' to the Nazi regime, which gave them confidence to begin the war. Radio broadcasting did not merely provide information, but it also encouraged people to join the war and Nazi projects up until the end of the Second World War.

Nazi Germany never stopped trying to form a communal identity and fuhrership through advertising propaganda even before Hitler and Nazi party gained absolute power in Germany. On one hand, Nazi Germany carried out the materialistic and practical message of the German ethnic community through endless wars and mass killings, such as the operation of extermination camps. On the other hand, Nazi Germany endeavored to expand the ideological meaning and legitimacy through various methods in propaganda until its ultimate defeat in 1945. According to Goebbels, who was the Reich minister of propaganda, it was possible for Nazi Germany to enlarge the abstract and symbolic meaning of the German community through airwaves.

\section{REFERENCES}

[1] A. A. Kallis, Nazi Propaganda and the Second World War, New York: Palgrave Macmillan, p. 17, 2005

[2] R. E. Herzstein, The War that Hitler Won: The Most Infamous Propaganda Campaign in History, New York: G. P. Putnam's Sons, p. 176, 1978.

[3] E. Kris and H. Speier, German Radio Propaganda: Report on Home Broadcastings during the War, London: Oxford University Press, pp. $52,1944$.
[4] E. Kris and H. Speier, German Radio Propaganda: Report on Home Broadcastings during the War, London: Oxford University Press, pp. 52, 1944, p. 54.

[5] E. H. Gombrich, Myth and Reality in German War-Time Broadcasts, London: The Athlone Press University of London, pp. 3-4, 1970.

[6] E. H. Gombrich, Myth and Reality in German War-Time Broadcasts, London: The Athlone Press University of London, 1970, p. 14.

[7] R. E. Herzstein, The War that Hitler Won: The Most Infamous Propaganda Campaign in History, New York: G. P. Putnam's Sons, pp. $155,1978$.

[8] E. H. Gombrich, Myth and Reality in German War-Time Broadcasts, London: The Athlone Press University of London, p. 4, 1970.

[9] A. A. Kallis, Nazi Propaganda and the Second World War, New York: Palgrave Macmillan, p. 34, 2005.

[10] R. E. Herzstein, The War that Hitler Won: The Most Infamous Propaganda Campaign in History, New York: G. P. Putnam's Sons, pp. 403, 1978.

[11] A. A. Kallis, Nazi Propaganda and the Second World War, New York: Palgrave Macmillan, p. 34, 2005.

[12] E. Kris and H. Speier, German Radio Propaganda: Report on Home Broadcastings during the War, London: Oxford University Press, pp. 58, 1944.

[13] A. A. Kallis, Nazi Propaganda and the Second World War, New York: Palgrave Macmillan, p. 2, 2005.

[14] A. A. Kallis, Nazi Propaganda and the Second World War, New York: Palgrave Macmillan, p. 13, 2005

[15] H. J. P. Bergmeier and R. E. Lots, Hitler's Airwaves: The Inside Story of Nazi Radio Broadcasting and Propaganda Swing, New Haven: Yale University Press, pp. 142, 1997

[16] R. E. Herzstein, The War that Hitler Won: The Most Infamous Propaganda Campaign in History, New York: G. P. Putnam's Sons, pp. 180, 1978.

[17] A. A. Kallis, Nazi Propaganda and the Second World War, New York: Palgrave Macmillan, pp. 35, 2005

[18] E. Kris and H. Speier, German Radio Propaganda: Report on Home Broadcastings during the War, London: Oxford University Press, p. $55,1944$.

[19] E. H. Gombrich, Myth and Reality in German War-Time Broadcasts, London: The Athlone Press University of London, p. 5, 1970.

[20] R. E. Herzstein, The War that Hitler Won: The Most Infamous Propaganda Campaign in History, New York: G. P. Putnam's Sons, p. $180,1978$.

[21] H. J. P. Bergmeier and R. E. Lots, Hitler's Airwaves: The Inside Story of Nazi Radio Broadcasting and Propaganda Swing, New Haven: Yale University Press, pp. 142, 1997

[22] R. E. Herzstein, The War that Hitler Won: The Most Infamous Propaganda Campaign in History, New York: G. P. Putnam's Sons, p. 181,1978 .

Youngho Yoo was born in South Korea, in April 1991, He received his B.A. from University of Toronto in history and classical civilization in Toronto, Canada, in 2016. And he is expected to get MA in Modern History at King's College London in 2017, in London, UK. 